\title{
From forests to cattail: how does the riparian zone influence stream fish?
}

\author{
Lilian Casatti ${ }^{1}$, Fabrício Barreto Teresa ${ }^{2}$, Thiago Gonçalves-Souza ${ }^{1}$, Eduardo Bessa ${ }^{3}$, \\ Angelo Rodrigo Manzotti ${ }^{1}$, Cristina da Silva Gonçalves ${ }^{4}$ and Jaquelini de Oliveira Zeni ${ }^{1}$
}

The aim of this study was to verify whether taxonomic and functional composition of stream fishes vary under three different preservation conditions of riparian zone: preserved (PRE), intermediate condition (INT), and degraded (DEG). Five stream stretches representing each condition were selected. Samples were taken from each stream in three occasions during the dry seasons from 2004 to 2007. Electro fishing (PRE and INT), sieves, dip nets, and hand seines (DEG) were used according to the characteristics of each sampled site. Overall, 46 species were registered. Differences in the taxonomic and functional species composition among groups were found, following the condition of riparian zones. The ichthyofauna recorded in the PRE was typical to pristine environments, consisting of species with specialized habits, notably benthic insectivores, intolerant, and rheophilics. In the INT group, replacement of riparian forest with shrubs and/or grasses created environmental conditions which favor the occurrence of tolerant species but also harbor a residual fauna of sensitive species. DEG streams presented mostly detritivores, tolerant, small sized fishes which occupy the surface and preferred slow water flux. Changes in the species composition were represented by the occurrence and dominance of tolerant species in detriment of the more sensitive and specialist species, following the gradient of degradation in the riparian zone. Forested streams act as unique habitats to many specialized species and it can be presumable that the degradation of riparian vegetation can generate biotic homogenization which may reduce species diversity and ecosystem services.

O presente estudo verificou se a composição taxonômica e funcional de peixes de riachos varia ao longo de três condições de preservação da zona ripária: preservada (PRE), preservação intermediária (INT) e degradada (DEG). Cinco riachos de cada grupo foram selecionados e amostras foram obtidas em cada riacho em três ocasiões em períodos secos de 2004 a 2007 . Pesca elétrica (PRE e INT), peneiras, puçás e redes de arrasto (DEG) foram usados de acordo com as características de cada local de coleta. No geral, 46 espécies foram registradas. Foram registradas diferenças na composição taxonômica e funcional de espécies entre os grupos, seguindo o gradiente de degradação da zona ripária. A ictiofauna encontrada em PRE foi típica de ambientes prístinos, consistindo em espécies de hábitos especializados, notavelmente bentônicas, insetívoras, intolerantes e reofílicas. No grupo INT, a substituição da floresta ripária por herbáceas ou gramíneas cria condições ambientais que favorecem a ocorrência de espécies tolerantes, mas também abriga uma fauna residual de espécies sensíveis. O grupo DEG foi representado principalmente por espécies detritívoras, tolerantes e de superfície. As modificações na composição de espécies foram representadas pela ocorrência e dominância de espécies tolerantes em detrimento da redução/eliminação daquelas mais sensíveis e especializadas, acompanhando o gradiente de degradação da zona ripária. Riachos florestados representam hábitats únicos para muitas espécies especializadas, sendo presumível esperar que a degradação da vegetação ripária cause homogeneização biótica que, por sua vez, pode reduzir a diversidade de espécies e os serviços ecossistêmicos.

Key words: Biotic homogenization, CWM analysis, Functional composition, Riparian forest, Species composition.

\section{Introduction}

Among the numerous functions of forested areas for streams (see Gregory et al., 1991; Naiman \& Décamps, 1997; Chapman \& Chapman, 2002; Pusey \& Arthington, 2003), specially riparian forests, two groups of processes stand out. One of them is the interception of sediments, fertilizers and pesticides that would otherwise enter the rivers through surface or subterranean draining (Naiman et al., 2005). Many studies confirm this mitigating role (e.g., Townsend \& Douglas, 2000;

\footnotetext{
${ }^{1}$ Universidade Estadual Paulista (UNESP), Laboratório de Ictiologia, Departamento de Zoologia e Botânica, IBILCE, Rua Cristóvão Colombo, 2265, 15054-000 São José do Rio Preto, SP, Brazil. licasatti@gmail.com

${ }^{2}$ Universidade Estadual de Goiás (UEG), Unidade Universitária de Porangatu, Av. Brasília, 32, 76550-000 Porangatu, GO, Brazil.

${ }^{3}$ Universidade do Estado de Mato Grosso (UNEMAT), Laboratório de Ecologia Comportamental da Reprodução, Rod MT 358 km 7 , 78300-000 Tangará da Serra, MT, Brazil.

${ }^{4}$ Universidade Estadual Paulista (UNESP), Departamento de Zoologia, Av. 24-A, 1515, 13506-900 Rio Claro, SP, Brazil.
} 
Lorion \& Kennedy, 2009) and demonstrate that a greater load of nutrients increases primary production and may promote eutrophication (Tundisi \& Tundisi, 2008); in addition, the increase of sedimentation rate has negative influence on feeding (Berkman \& Rabeni, 1987; Rabeni \& Smale, 1995), foraging capacity (Berkman \& Rabeni, 1987) and fish larvae development (Morgan et al., 1983). The second group of processes includes the exchange of organic matter between the terrestrial and aquatic ecosystems. Allochthonous organic matter, such as leaves and branches, serves as substrate for the development of microorganisms taken as food by invertebrates and fishes (e.g., Angermeier \& Karr, 1983; Pusey \& Arthington, 2003), offers shelters for ichthyofauna (Angermeier \& Karr, 1983), works as visual reference that helps visual guidance and navigation for fishes (Crook \& Robertson, 1999) as well as influences the hydraulic profile of water courses (Brooks et al., 2004; Daniels \& Rhoads, 2004). There is evidence that the reduced intake of these elements may cause a reduction in species number, density and biomass of fishes (Angermeier \& Karr, 1983; Neumann \& Wildman, 2002; Lester et al., 2007; Schneider \& Winemiller, 2008). Additionally, there is much evidence that the patterns of assemblages are also influenced by the width and type of adjacent forest covering (Bojsen \& Barriga, 2002; Lorion \& Kennedy, 2009; Casatti et al., 2009; Teresa \& Romero, 2010).

In regions with gentle slopes, it is possible to identify that the gradual loss of habitat quality is associated to the degradation of forest close to rivers, almost always result of the increase in sediment and higher insolation in the water course. In situations of high integrity of the surrounding forest (Fig. 1a), the ichthyofauna generally presents high species richness, low dominance, absence of exotic species and high contribution of allochthonous items (seeds, fruits and terrestrial arthropods) in the diet of its fishes (Lorion \& Kennedy, 2009; Ferreira, 2010). On the other hand, in an intermediate stage of preservation (Fig. 1b), there is generally the replacement of native specialists by other exotic species, that are tolerant to hypoxia and to high temperature, loss of rheophilic species, decrease of biomass and major chances of biotic homogenization (Casatti et al., 2009; Ferreira, 2010; Teresa \& Casatti, 2010). Where the stream bed is embedded with thin sediments, the habitat volume and the water current are reduced, characterizing extreme siltation (Fig. 1c), there are favorable conditions to the establishment of rooted macrophytes, especially cattails of the genus Typha. In this situation, ichthyofauna is dominated by accidental and opportunists species capable of consuming organic detritus which became the dominant food item under such circumstances (Rocha et al., 2009).

Degradation gradient is commonly observed in streams of southeastern Brazil, where the advance of agriculture and livestock throughout the decades has resulted in the suppression of most of the native vegetation, including riparian forests (Silva et al., 2007). This situation represents an opportunity to investigate the aquatic communities' response to the gradients of environmental disturbances.

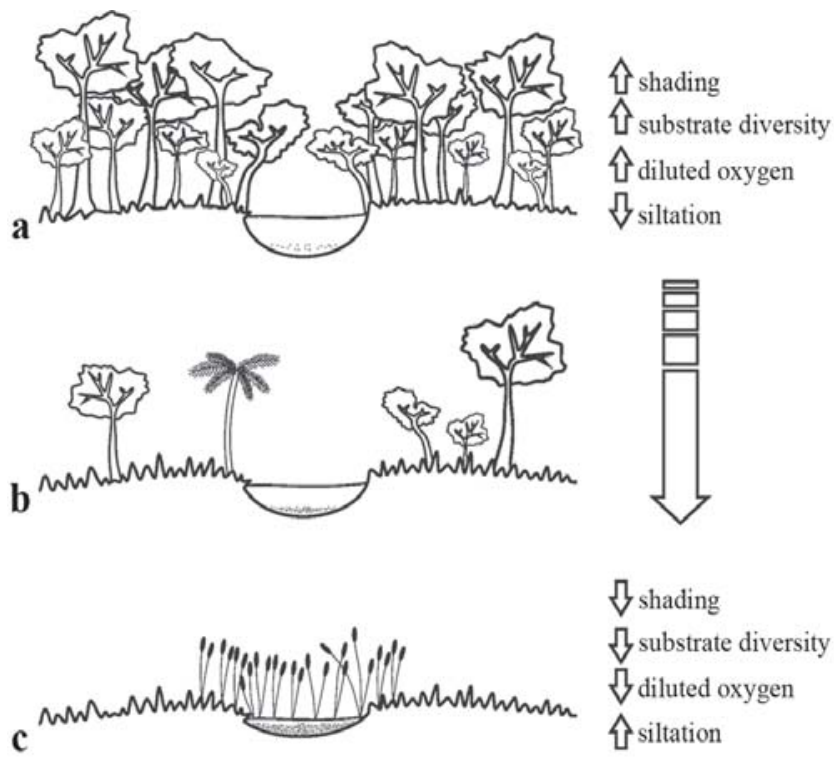

Fig. 1. Characteristic stages of the degradation process of riparian zones in a stream. a) streams with preserved riparian forests (PRE); b) with riparian forests in intermediate stage of degradation (INT); c) without riparian forests and in advanced stage of degradation (DEG).

This study then verified if the taxonomic and functional composition varied according to the degradation gradient of the riparian zone, inferred by the characterization of the surrounding vegetation to the streams: forests, representing the most preserved sites (hereafter PRE); shrubs and grasses, indicating intermediate degree of perturbation (hereafter INT); cattails of the genus Typha, indicating degradation (hereafter DEG). We predict that (i) the taxonomic composition will be different among the different stream groups, (ii) the communities will be composed by species with different traits among the stream groups, with dominance of specialist species (e.g., insectivore-rheophilic species) associated with PRE streams, generalist (e.g., omnivore) species associated with DEG streams and a combined species composition in INT streams.

\section{Material and Methods}

Study site. Study sites are located in the northwestern state of São Paulo, in the São José dos Dourados and TurvoGrande basins, which drains an area of 2,327,000 ha (Nalon et al., 2008). In this area are predominant igneous basalt rocks of Serra Geral formation, sedimentary rocks of the Bauru and Cauiá groups surface, with inputs from Botucatu and Piramboia sand formations as deep aquifers (IPT, 2000), which makes the soil highly susceptible to erosion (Silva et al., 2007). Climate is classified as hot tropical, with maximum mean temperatures ranging from 31 to $32^{\circ} \mathrm{C}$, and minimum mean temperatures from 13 to $14^{\circ} \mathrm{C}$. The average annual rainfall ranges from 1,300 to $1,800 \mathrm{~mm}$ (Nimer, 1989). 
According to a recent survey (Nalon et al., 2008), only 3.6\% of the area of the São José dos Dourados and $3.7 \%$ in the Turvo-Grande basin are covered by natural vegetation. The remaining area is predominantly used by pasture and sugar cane, including the riparian zones (Silva et al., 2007).

Sampling. Several environmental factors influence the structure of fish assemblage on different spatial scales (Tejerina-Garro et al., 2005). In order to minimize such influences for this study, criteria for stream selections were: to have similar dimensions (Table 1) and to be situated in the same geographic area, subject to similar land uses. Fifteen stream stretches were selected (Fig. 2), with five sites in each of three groups (PRE, INT, or DEG, see Fig. 1), and were sampled on three occasions in the dry seasons of 2004 to 2007. Selected stretches of the groups PRE and INT were of $75 \mathrm{~m}$ length, isolated with block nets ( $5 \mathrm{~mm}$ mesh) and the collection of fish was performed using two upstream passes of electric fishing (stationary generator, AC, $220 \mathrm{~V}, 50-60 \mathrm{~Hz}$, 3.4-4.1 A, $1000 \mathrm{~W}$ ). Length of each DEG stretch was determined based on the collection equipment maneuverability, since instream habitat was covered by cattail at most sites. In these DEG sites isolated with block nets ( $5 \mathrm{~mm}$ mesh), two circular sieves ( $3 \mathrm{~mm}$ mesh, $60 \mathrm{~cm}$ diameter), two V-shaped dip nets (3 $\mathrm{mm}$ mesh), and a hand seine ( $2 \mathrm{~m}$ width $\mathrm{x} 1.5 \mathrm{~m}$ height, $3 \mathrm{~mm}$ mesh) were applied for 15 minutes each equipment by two collectors. Different sampling methods were used in order to maximize fish collection in each group. As far as we know, the method used for each group is the most appropriate considering their physical conditions and restrictions. For example, the utilization of electric fishing in DEG streams is difficult considering depth and the amount of macrophytes. Caught fish were fixed in 10\% formalin solution and, after 48 hours, transferred to $70 \%$ solution of ethanol. Voucher specimens are deposited in the fish collection at the Departamento de Zoologia e Botânica da Universidade
Estadual Paulista (DZSJRP), São José do Rio Preto, in the state of São Paulo, Brazil.

Analysis. To assess sampling efficiency, a sample-based rarefaction curve (Mao-Tau) was calculated along with the Chao 1 richness estimator, the best to be used when variation coefficient is $>0.5$, using the software EstimateS 7.5.2 (Cowell, 2005). Previously, the temporal variation of samples was tested by using the analysis of similarity (ANOSIM, Jaccard coefficient) and since no significant influence of the sampling period $(\mathrm{R}=-0.178, \mathrm{p}=0.990)$ was detected, pooled samples were used to assess similarity between sites. ANOSIM was used to test if species composition is influenced by the degradation gradient; in this analysis an $\mathrm{R}$ value is generated, which indicates the relationship between the mean dissimilarity among groups of samples with the mean dissimilarity within each group. The chance of differences in the composition of species between groups is generated by permutations. The similarity between groups of streams was evaluated by the binary Jaccard index and its respective variance (Bootstrap method, $\mathrm{n}=200$ iterations) using the software SPADE (Chao \& Shen, 2010). To ordinate sites, Nonmetric Multidimensional Scaling Analysis was conducted using the Primer 6 software (Clarke \& Gorley, 2006) and its interpretation (Clarke \& Warwick, 2001).

To represent the spatial variation an analysis called Principal Coordinates of Neighbor Matrices (PCNM) was perfoemed (Dray et al., 2006). Recent studies showed that watercourse distance is able to capture spatial patterns that are not captured by overland distances (e.g., obtained from latitude and longitude data) (Landeiro et al., 2011). To perform the PCNM analysis, watercourse distances among sampling points were generated from Soil and Water Assessment Tool, using drainage net with 150 ha produced by the Digital Elevation Model (90 m of resolution) with the help of the software ArcGIS 9.3 (ESRI, 2008). To each site was generated

Table 1. Average value of abiotic variables in each site: temperature $\left({ }^{\circ} \mathrm{C}\right), \mathrm{pH}$, dissolved oxygen $(\mathrm{mg} / \mathrm{l})$, conductivity $\left(\mu \mathrm{S} / \mathrm{cm}^{2}\right)$, turbidity (NTU), depth $(\mathrm{m})$, width $(\mathrm{m})$, current $(\mathrm{m} / \mathrm{s})$, and predominant substrate $(1=100-75 \%$ sand; $2=74-50 \%$ of sand and the remaining of consolidated substrate; $3=49-25 \%$ of sand and the remaining of consolidated substrate; $4=<25 \%$ of sand and the remaining of consolidated substrate).

\begin{tabular}{|c|c|c|c|c|c|c|c|c|c|}
\hline Sites & Temperature & $\mathrm{pH}$ & $\begin{array}{c}\text { Dissolved } \\
\text { oxygen }\end{array}$ & Conductivity & Turbidity & Depth & Width & Current & Substrate \\
\hline PRE1 & 15.6 & 8.45 & 6.2 & 0.123 & 0 & 0.3 & 1.3 & 0.1 & 4 \\
\hline PRE2 & 15.6 & 7.74 & 9.5 & 0.113 & 30 & 0.3 & 3.2 & 0.2 & 4 \\
\hline PRE3 & 16.5 & 7.98 & 8.7 & 0.060 & 19 & 0.2 & 1.5 & 0.3 & 4 \\
\hline PRE4 & 17.3 & 7.96 & 8.5 & 0.085 & 12 & 0.4 & 2.2 & 0.2 & 3 \\
\hline PRE5 & 22.7 & 6.80 & 9.7 & 0.024 & 9 & 0.2 & 1.7 & 0.3 & 3 \\
\hline INT1 & 17.8 & 6.61 & 6.6 & 0.047 & 3 & 0.3 & 3.2 & 0.3 & 2 \\
\hline INT2 & 19.7 & 6.07 & 7.6 & 0.043 & 7 & 0.4 & 1.6 & 0.5 & 2 \\
\hline INT3 & 21.0 & 7.50 & 8.0 & 0.057 & 28 & 0.4 & 1.6 & 0.5 & 2 \\
\hline INT4 & 18.9 & 7.62 & 3.9 & 0.093 & 20 & 0.9 & 2.6 & 0.1 & 2 \\
\hline INT5 & 20.8 & 7.26 & 6.3 & 0.064 & 5 & 0.7 & 2.3 & 0.4 & 2 \\
\hline DEG1 & 16.5 & 7.00 & 3.2 & 0.078 & 129 & 0.8 & 1.5 & 0.4 & 1 \\
\hline DEG2 & 19.6 & 7.39 & 2.7 & 0.125 & 90 & 0.9 & 2.9 & 0.2 & 1 \\
\hline DEG3 & 19.9 & 7.50 & 1.5 & 0.179 & 14 & 0.9 & 4.2 & 0.1 & 1 \\
\hline DEG4 & 18.2 & 7.37 & 2.6 & 0.103 & 52 & 0.3 & 1.5 & 0.4 & 1 \\
\hline DEG5 & 18.1 & 7.67 & 3.2 & 0.139 & 61 & 1 & 2.7 & 0.4 & 1 \\
\hline
\end{tabular}




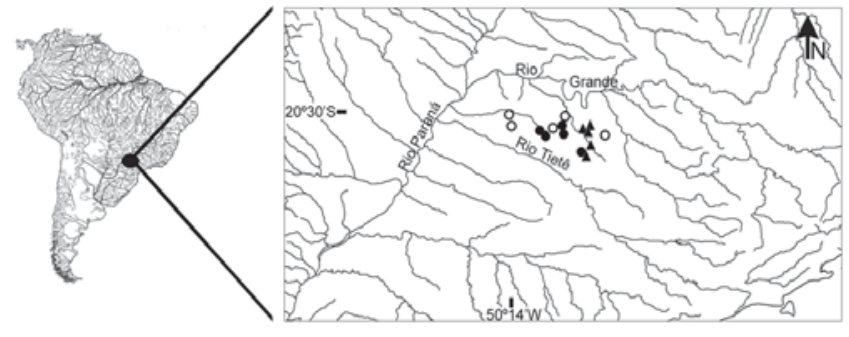

Fig. 2. Location of the preserved (PRE, open circles), intermediate (INT, dark circles), and degraded (DEG, triangles) sites in the northwestern portion of the state of São Paulo, Brazil.

a file with distance values to all the net drainage, resulting in a triangular matrix. Then, a matrix of truncated distance was calculated to retain the distance among neighbors. A Principal Coordinate Analysis (PCoA) of the truncated matrix was computed, and its positive eigenvectors were retained (Borcard et al., 2011) to be used as spatial predictors (Borcard et al., 2002; Dray et al., 2006).

A Partial Redundancy Analysis (pRDA) with a Variation Partitioning method (Borcard \& Legendre, 2002) was used to quantify the relative importance of environmental (see below) and spatial variables (positive PCNM eigenvectors) in explaining the variation in species composition. First, the RDA decomposes the total explained variation into environmental and spatial components. Then, the unbiased Variation Partitioning method proposed by Peres-Neto et al. (2006) was used to obtain the variance explained exclusively by environmental and spatial components, and their respective adjusted coefficients of determination $\left(R_{a d j}{ }^{2}\right)$. Environmental (abiotic) variables were measured in each field incursions. Hydrogenionic potential, dissolved oxygen, conductivity, temperature, and turbidity were measured with electronic equipment; current, depth and width were measured in several points along the stretch; substrate composition was visually evaluated in sand and consolidated types (rocks, gravels, pebbles). Prior to analyses, all abiotic variables were standardized to mean 0 and standard deviation 1 . The R language-environment (R Development Core Team, 2011) and its packages vegan and PCNM were used to run $\mathrm{pRDA}$ and PCNM analyses.

In order to identify indicator species in groups of streams, an Indicator Species Analysis (IndVal), complemented by the multi-levels pattern analysis was performed using the "multipatt" function in the "indicspecies" package of the software R 2.11.1 (R Development Core Team, 2011). This function considers all possible combinations of groups of sites and selects the combination for which the species can be best used as indicator (De Cáceres et al., 2010). This analysis was carried out with a presence/absence matrix.

To evaluate the functional composition, the species were classified in relation to five traits based on information from literature and personal observations: (i) trophic group (Aquins, insectivores with predominance of aquatic forms; Carn, carnivores with predominance of invertebrates and fishes; Detr, detritivores; Omni, omnivores; Perif, periphytivores), (ii) habitat use (Bent, benthic; Nek, nektonics; Nekto, nektobenthic; Nekto/Bank, nektobenthic associated with stream banks; Surf, close to the surface of the water), (iii) size (Small, $<50 \mathrm{~mm}$; Medium, 50-150 mm; Large, $>150 \mathrm{~mm}$ ), (iv) preference for current (arbitrarily classified in Slow; Medium; Fast) and (v) hypoxia tolerance (Tol, tolerant; Int, intolerant). In order to investigate if the functional composition of the streams groups are different, the community weighted mean of a trait values (CWM), a functional composition index defined as the mean of values present in the community weighted by the relative abundance of taxa bearing each value (Lavorel et al., 2008), was obtained for each sample. This analysis was performed by using the "dbFD" function in the "FD" package of the software R 2.11.1 (R Development Core Team, 2011). When nominal traits are used, as in this study, the CWM highlights the trait exhibited by the dominant species in each community.

\section{Results}

Sampling efficiency assessment revealed that six additional species could be registered in PRE group, and three in INT and DEG groups (Fig. 3). Overall, 46 species were registered; 25 species in the DEG group, and 30 species in the PRE and in the INT groups (Table 2). Species composition among groups were different (ANOSIM, $\mathrm{R}_{\text {global }}=0.455, \mathrm{p}<0.01$ ). The species composition of PRE streams was different to INT and DEG streams $\left(\mathrm{R}_{\text {PRExINT }}=0.354, \mathrm{p}=0.02 ; \mathrm{R}_{\text {PRExDEG }}=0.67, \mathrm{p}=0.01\right)$ (Fig. 4). However, INT and DEG streams showed no differences in relation to species composition $\left(\mathrm{R}_{\mathrm{INTXDEG}}=0.326, \mathrm{p}=0.09\right)$ (Fig. 4). The sharing of species inferred by the Jaccard index was greater between INT-PRE and INT-DEG (mean $0.46 \pm 0.05$ and $0.53 \pm 0.05$, respectively) than between PRE-DEG $(0.34 \pm$ 0.04) (Fig. 4). About half the species found in PRE (47\%) were not found in DEG group.

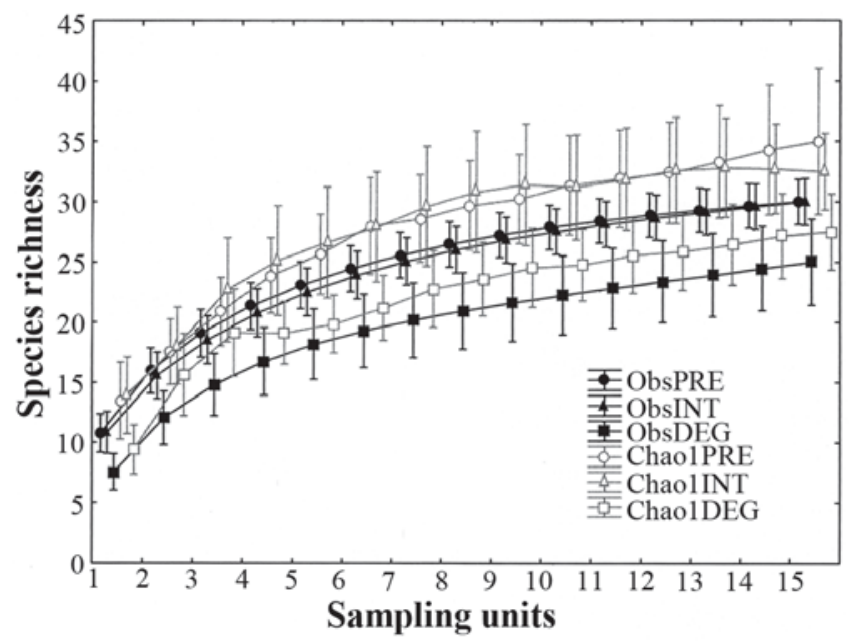

Fig. 3. Sample-based rarefaction curve (Obs) and richness estimation curves (Chao 1) by 50 randomizations against cumulative samples of the preserved (PRE), intermediate (INT), and degraded (DEG) sites. 
Table 2. Collected species, frequency of occurrence in each stream group (PRE, preserved; INT, intermediate; DEG, degraded). $\mathrm{E}=$ following species name indicates exotic species. Values marked in bold indicate the habitat or combination of habitats where species were significantly associated, according to IndVal analysis. Species features included: trophic group (Aquins, insectivores with predominance of aquatic forms; Carn, carnivores with predominance of invertebrates and fishes; Detr, detritivores; Omni, omnivores; Perif, periphytivores), habitat use (Bent, benthic; Nek, nektonics; Nekto, nektobenthic; Nekto/ Bank, nektobenthic associated with stream banks; Surf, close to the surface of the water), size (Small, <50 mm; Medium, 50$150 \mathrm{~mm}$; Large, $>150 \mathrm{~mm}$ ), preference for current (arbitrarily classified in Slow; Medium; Fast) and hypoxia tolerance (Tol, tolerant; Int, intolerant). ${ }^{1}$ Andrian et al. (1994), Castro \& Casatti (1997), Uieda et al. (1997), Gibran et al. (2001), Casatti (2002), Ferreira \& Casatti (2006) and Rocha et al. (2009). ${ }^{2}$ Casatti \& Castro (1998), Casatti et al. (2001), Casatti (2002) and personal observations. ${ }^{3}$ Personal observations and data from Fishbase (www.fishbase.org). ${ }^{4}$ Kramer \& Mehegan (1981), Araujo \& Garutti (2003), Bozzetti \& Schulz (2004) and Casatti et al. (2006).

\begin{tabular}{|c|c|c|c|c|c|c|c|c|}
\hline Species & PRE & INT & DEG & Trophic $^{1}$ & Habitat use $^{2}$ & Size $^{3}$ & Current $^{2}$ & Tolerance $^{4}$ \\
\hline Aspidoras fuscoguttatus & 60 & 60 & 60 & Aquins & Bent & Small & Fast & Tol \\
\hline Astyanax altiparanae & 100 & 60 & 100 & Omni & Nek & Medium & Slow & Int \\
\hline Astyanax bockmanni & - & 20 & - & Omni & Nek & Medium & Slow & Int \\
\hline Astyanax fasciatus & 100 & 60 & 60 & Omni & Nek & Medium & Slow & Int \\
\hline Astyanax paranae & - & - & 60 & Aquins & Nek & Medium & Slow & Int \\
\hline Bryconamericus stramineus & 40 & - & - & Aquins & Nek & Small & Slow & Int \\
\hline Callichthys callichthys & - & 60 & 20 & Omni & Bent & Medium & Fast & Tol \\
\hline Cetopsorhamdia iheringi & 40 & - & - & Aquins & Bent & Medium & Fast & Int \\
\hline Characidium gomesi & 20 & - & - & Aquins & Bent & Medium & Fast & Int \\
\hline Characidium zebra & 80 & - & - & Aquins & Bent & Medium & Fast & Int \\
\hline Cheirodon stenodon & 20 & - & 20 & Aquins & Nek & Small & Slow & Int \\
\hline Corydoras aeneus & - & 100 & 80 & Omni & Bent & Small & Medium & Tol \\
\hline Crenicichla britskii & 20 & 40 & 20 & Aquins & Nekto/Bank & Medium & Medium & Int \\
\hline Cyphocharax modestus & - & - & 20 & Detr & Nekto & Medium & Medium & Int \\
\hline Cyphocharax vanderi & 20 & 20 & - & Detr & Nekto & Medium & Medium & Int \\
\hline Eigenmannia virescens & 40 & 20 & - & Aquins & Nekto/Bank & Medium & Medium & Int \\
\hline Erythrinus erythrinus & - & 40 & 60 & Carn & Nekto/Bank & Large & Slow & Tol \\
\hline Geophagus brasiliensis & 40 & 20 & 40 & Omni & Nekto & Large & Slow & Tol \\
\hline Gymnotus sylvius & 80 & 100 & 100 & Aquins & Nekto/Bank & Large & Medium & Tol \\
\hline Hisonotus francirochai & 20 & 20 & - & Omni & Nekto/Bank & Small & Medium & Int \\
\hline Hoplias malabaricus & 60 & 60 & - & Carn & Nekto/Bank & Large & Slow & Tol \\
\hline Hoplosternum littorale & - & 20 & 20 & Detr & Nekto & Large & Slow & Tol \\
\hline Hyphessobrycon anisitsi & - & - & 60 & Aquins & Nek & Small & Slow & Tol \\
\hline Hypostomus ancistroides & 100 & 100 & 40 & Perif & Bent & Medium & Fast & Tol \\
\hline Hypostomus nigromaculatus & 60 & 60 & - & Perif & Bent & Medium & Fast & Int \\
\hline Imparfinis mirini & - & 40 & - & Aquins & Bent & Medium & Fast & Int \\
\hline Imparfinis schubarti & 80 & 20 & 80 & Aquins & Bent & Medium & Fast & Int \\
\hline Knodus moenkhausii & 20 & - & - & Aquins & Nek & Small & Medium & Tol \\
\hline Leporinus friderici & 20 & - & - & Aquins & Nekto & Medium & Medium & Int \\
\hline Leporinus striatus & 20 & - & - & Aquins & Nekto & Medium & Medium & Int \\
\hline Oligosarcus pintoi & 20 & 80 & 20 & Aquins & Nekto/Bank & Medium & Slow & Int \\
\hline Oreochromis niloticus $\mathrm{E}$ & - & 20 & - & Omni & Nekto & Large & Slow & Tol \\
\hline Parodon nasus & 20 & - & - & Perif & Bent & Medium & Fast & Int \\
\hline Phalloceros harpagos & 20 & 60 & 60 & Detr & Surf & Small & Slow & Tol \\
\hline Phenacorhamdia tenebrosa & 20 & - & - & Aquins & Bent & Medium & Fast & Int \\
\hline Piabina argentea & 80 & 80 & - & Omni & Nek & Small & Medium & Int \\
\hline Pimellodela avanhandavae & 60 & 20 & 40 & Aquins & Bent & Medium & Medium & Int \\
\hline Poecilia reticulata $\mathrm{E}$ & 40 & 80 & 80 & Detr & Surf & Small & Slow & Tol \\
\hline Pseudopimelodus pulcher & 20 & - & - & Aquins & Bent & Medium & Fast & Int \\
\hline Pterygoplichthys ambrosettii & - & - & 20 & Perif & Bent & Large & Medium & Tol \\
\hline Rhamdia quelen & 100 & 80 & 60 & Aquins & Bent & Medium & Medium & Tol \\
\hline Serrapinnus heterodon & - & - & 20 & Detr & Nek & Small & Slow & Tol \\
\hline Serrapinnus notomelas & - & 40 & 20 & Detr & Nek & Small & Slow & Tol \\
\hline Steindachnerina insculpta & - & 20 & 20 & Detr & Nekto & Medium & Slow & Int \\
\hline Synbranchus marmoratus & - & 20 & - & Carn & Nekto/Bank & Large & Medium & Tol \\
\hline Tilapia rendalli $\mathrm{E}$ & - & 20 & - & Omni & Nekto & Large & Slow & Tol \\
\hline
\end{tabular}

By comparing fish species composition among stream groups, abiotic and spatial components explained together $33 \%$ of the variation $\left(R_{a d j}^{2}=0.33, \mathrm{p}<0.0001\right)$. However, partitioning the variation explained solely by each component, abiotic variables accounted for $26 \%\left(R_{a d j}^{2}=\right.$ $0.27, \mathrm{p}<0.0001)$ and the spatial predictors for $5 \%\left(R_{a d j}{ }^{a}=\right.$
$0.05, \mathrm{p}=0.036)$ of the variation in fish species composition. The most important abiotic variables for species composition were dissolved oxygen $(\mathrm{F}=8.38, \mathrm{p}=0.001)$, $\mathrm{pH}(\mathrm{F}=4.16, \mathrm{p}=0.001)$, and substrate $(\mathrm{F}=3.45, \mathrm{p}=0.001)$, although conductivity, turbidity, and current were significant (Fig. 5). 


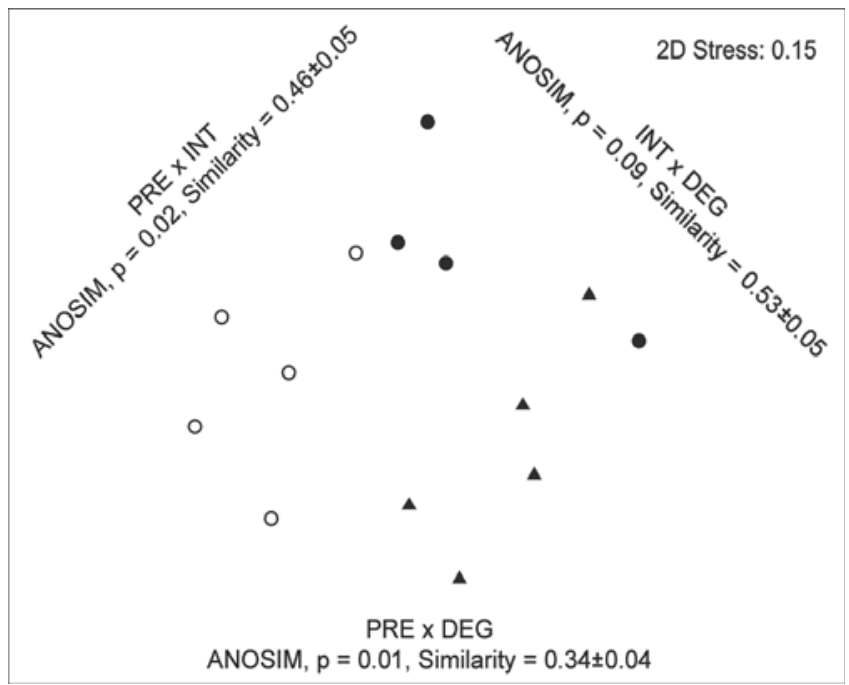

Fig. 4. Biplot resulting from Nonmetric Multidimensional Scaling Analysis (NMDS) with presence and absence data showing ordination of sample units that represent each stream group: preserved (PRE, open circles), intermediate (INT, dark circles), and degraded sites (DEG, triangles). NMDS biplot exhibited stress value of 0.15 in 2 -dimension, indicating good to potential useful interpretation (Clarke \& Warwick, 2001).

Some species (such as Aspidoras fuscogutattus, Astyanax altiparanae, A. fasciatus, Crenicichla britskii, Geophagus brasiliensis, Gymnotus sylvius, Hypostomus ancistroides, Imparfinis schubarti, Oligosarcus pintoi, Phalloceros harpagos, Pimelodella avanhandavae, Poecilia reticulata, and Rhamdia quelen) had broad occurrence along the gradient and 20 species occurred exclusively in one of the stream groups. From those, ten occurred in PRE streams, while five species were registered exclusively in INT and DEG (Table 2). The Indicator Species Analysis revealed that three species were significantly associated to one or combination of groups. Characidium zebra was indicative of PRE $(\mathrm{p}=0.01)$, Piabina argentea of PRE and INT $(\mathrm{p}=0.02)$ and Corydoras aeneus of INT and DEG $(\mathrm{p}<0.01)$ (Table 2$)$.

The communities varied in functional composition (Table 3). Overall, PRE communities were mostly represented by intolerant, insectivore and benthic species, of medium size and having preference for intermediate to fast water current. DEG streams presented mostly detritivores, tolerant, small sized fishes which occupy the surface and preferred slow water current. Intermediate streams presented a more variable functional composition, with streams showing distinct fish dominant characteristics. Differently to the other groups, two INT streams presented dominance of large fishes inhabiting marginal areas close to the banks (Table 3).

\section{Discussion}

The results obtained here indicates that the fish community composition reflects the progressive loss of

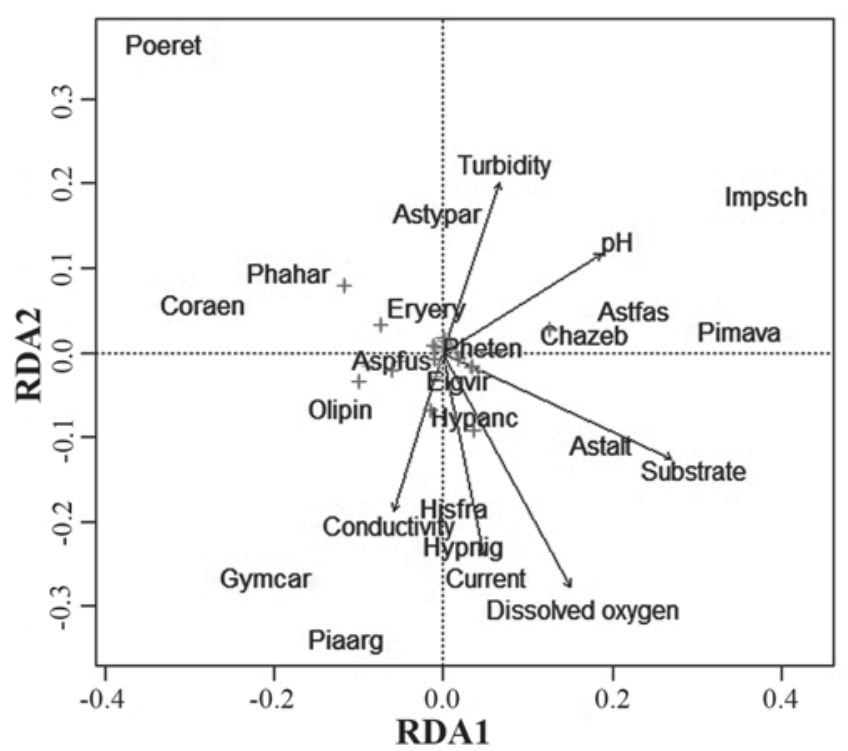

Fig. 5. Biplot of the Partial Redundancy Analysis (pRDA) on fish species composition (see abbreviations on Table 2) and abiotic variables relationships (arrows). Species with low abundance were not represented in the biplot following the option "orditorp r" in the package vegan of the software R 2.11.1.

vegetation quality in the riparian zone. The changes in species composition occurred mainly between preserved streams and those in intermediate and degraded stages condition, representing responses that are common in aquatic communities exposed to gradients of habitat degradation (Kikuchi \& Uieda, 1998; Cortezzi et al., 2009; Johnson \& Hering, 2009). Changes in the species composition observed in this study were also accompanied by functional composition changes in communities, represented by the dominance of tolerant and opportunist fishes, in detriment to the diminution/ elimination of more sensitive and specialized species along the degradation gradient of riparian zone.

The community represented in PRE is typical of pristine environments, with one-third of its species not occurring in the other groups of streams, including the only indicator species in this group (Characidium zebra). Most of the species are dependent on specific resources and conditions (e.g., availability of rocky substrates, presence of logs and branches, hydraulic variability and availability of allochthonous food in the instream habitat, high dissolved oxygen, low turbidity) common in preserved streams (Casatti et al., 2006; Lorion \& Kennedy, 2009). In fact, the loss of key meso- and microhabitats is one of the results of the riparian vegetation suppression and it is probably related to the absence of these species in INT and DEG streams.

In an intermediary stage, the replacement of riparian forests by bushes or grasses generates environmental conditions that favor the occurrence of tolerant species (e.g., Aspidoras fuscoguttatus, Callichthys callichthys, Corydoras aeneus, Gymnotus spp., Poecilia reticulata), the establishment of 
Table 3. Results of the community weighted mean of a trait (CWM) analysis for streams groups (PRE, preserved; INT, intermediate; DEG, degraded). Species features included: trophic group (Aquins, insectivores with predominance of aquatic forms; Carn, carnivores with predominance of invertebrates and fishes; Detr, detritivores; Omni, omnivores; Perif, periphytivores), habitat use (Bent, benthic; Nek, nektonics; Nekto/Bank, nektobenthic associated with stream banks; Surf, close to the surface of the water), size (Small, $<$ $50 \mathrm{~mm}$; Medium, 50-150 mm; Large, > $150 \mathrm{~mm}$ ), preference for current (arbitrarily classified in Slow; Medium; Fast) and hypoxia tolerance (Tol, tolerant; Int, intolerant).

\begin{tabular}{cccccc}
\hline Groups & Diet & Habitat use & Size & Current & Tolerance \\
\hline PRE & Aquins & Bent & Medium & Slow & Int \\
PRE & Aquins & Bent & Medium & Fast & Int \\
PRE & Aquins & Bent & Medium & Medium & Int \\
PRE & Aquins & Bent & Medium & Fast & Int \\
PRE & Perif & Bent & Small & Medium & Int \\
INT & Aquins & Bent & Medium & Medium & Int \\
INT & Aquins & Nekto/Bank & Large & Medium & Tol \\
INT & Omni & Nek & Medium & Slow & Int \\
INT & Detr & Surf & Small & Slow & Int \\
INT & Aquins & Nekto/Bank & Large & Medium & Tol \\
DEG & Aquins & Nek & Medium & Slow & Int \\
DEG & Detr & Surf & Small & Slow & Tol \\
DEG & Detr & Surf & Small & Slow & Tol \\
DEG & Detr & Surf & Small & Slow & Int \\
DEG & Omni & Nek & Medium & Slow & Tol \\
\hline
\end{tabular}

exotic species (Oreochromis niloticus, Poecilia reticulata, Tilapia rendalli), but still houses a residual fauna of sensitive species (e.g., Imparfinis schubarti, Hypostomus nigromaculatus, Eigenmannia virescens, Crenicichla britskii). This indicates that changes in the fish community follow the degradation gradient, as may be verified by the major similarity found between INT-PRE and INT-DEG. For many species, the INT streams represent the limit of their distribution in the degradation gradient. For instance, Piabina argentea was considered indicative of PRE and INT sites. This species has opportunistic and generalist habits, able to tolerate some degree of anthropogenic degradation (Ferreira et al., 2002; Ferreira \& Casatti, 2006), disappearing in extreme stages of degradation like the streams of the DEG group. On the other hand, habitat degradation favors other species, such as Corydoras aeneus, a detritivore and tolerant species, indicative of low environmental quality (Casatti et al., 2010), capable of exploring the resources and conditions that become abundant in degraded environments (Rocha et al., 2009).

Besides the taxonomic composition, changes in the fish communities' functional composition were registered along the degradation gradient of riparian forest. The dominant characteristics of fish from streams with preserved riparian forest (e.g., insectivore diet, benthic habit, preference for fast water current and intolerance) are normally associated to fish that live in riffles (Casatti \& Castro, 1998; see Table 3) that are common mesohabitats in preserved environments. When streams are exposed to riparian forest loss and siltation, riffles tend to disappear (Rabeni \& Smale, 1995), and under these conditions, stretches with slow water current tend to predominate, which probably explains the dominance of fish with affinity to slow water current in INT and DEG. Lorion \& Kennedy (2009) observed the increase of detritivores and herbivores in streams without riparian vegetation in comparison to forested streams and similar results obtained in other studies indicate that this changes is probably associated to a change in the availability of food along the degradation gradient (Burcham, 1988; Bojsen \& Barriga, 2002; Carvalho \& Uieda (2010). Rocha et al. (2009) highlighted that in deforested streams, with the predominance of cattails, detritus can be retained among roots of the macrophytes, favored by the slow water current and the large quantity of submerged organic matter. Besides the detritivore diet, fish from DEG streams also exhibits a particular combination of traits, such as surface dwelling, small size and tolerance to low levels of dissolved oxygen. The dominance of these characteristics happens mainly due to the differential contribution of two species, Phalloceros harpagos and Poecilia reticulata. The small body size and the use of surface stratum may favor the permanence and dislocation of these species in places where instream habitat is most occupied by cattails. In such environments, low levels of dissolved oxygen are common and may explain the dominance of fish tolerant to hypoxia.

The major functional variation found among INT stretches reflects a variation of the quantitative structure of the communities and the influence of species from both ends of the gradient. In this context, a combination of typical characteristics of pristine communities (e.g., insectivore diet, benthic habit and intolerance to hypoxia), with characteristics of communities from degraded environments (e.g., detritivore diet, surface dwelling, preference for slow water current and tolerance to hypoxia) is expected. Moreover, the use of the margins and outstanding large size fish in INT streams are probably related to the abundance of herbaceous vegetation along the banks of these streams, facilitating the occurrence of species that use this microhabitat as a refuge and feeding site (Growns et al., 2003; Casatti et al., 2009), as, for instance, is the case of Gymnotiforms (Teresa \& Romero, 2010). The abundance of herbaceous vegetation present in INT streams may also explain the dominance of large fish, since these structures may represent a protection against predation, mainly considering that large fish tend to be more susceptible to terrestrial predators (Power, 1984; Harvey \& Stewart, 1991). Additionally, in accordance to the registers in other freshwater environments, microhabitat hydraulics plays a more important role as a template for species ecological strategies (Blanck et al., 2007), since it can restrains the 
occurrence of large size fish in PRE streams, where fast flow stretches are more common, and in DEG streams, that have a greater portion of the habitat occupied by cattails, limiting fish maneuverability.

Some studies show that, to protect aquatic biodiversity and assure the ecological processes in lotic environments, it is necessary to protect most of the river basins, since only the restoration of riparian zones close to the rivers is insufficient to improve the integrity of the whole system (Harding et al., 1998; Teels et al., 2006 and authors therein, Lévêque et al., 2008). If protection of most of the river basins is not possible in heavily agricultural basins, wooded riparian cover could be effective in maintaining and improving fish community composition in streams (Stauffer et al., 2000) and such conclusions are valid here when one considers that most of the soil of the studied region is intensely used for food or fuel production (Silva et al., 2007). Nevertheless, in many regions not even the riparian zones are protected, as pointed by Silva et al. (2007) in studies which demonstrate that some areas of the Southeastern region of Brazil has less than $25 \%$ of its riparian areas with forests. In the long term, the environmental pressures coming from the absence of riparian zone protection, particularly the river bed covering by thin sediments, the habitat volume reduction and the development of rooted aerial macrophytes (Bunn et al., 1997), drive the streams to a condition similar to that observed in DEG.

Together, these results indicate that the stream fish fauna responds to the degradation gradient of the riparian vegetation, through a change in its species composition and functional characteristics. Communities become dominated by opportunist and tolerant species, as is typical of low integrity environments (Casatti et al., 2009). On the other hand, the streams with preserved riparian vegetation represent refuges for fish fauna from the taxonomic and functional point of view. With the loss of sensitive and functionally specialized species in degraded riparian vegetation and instream habitat, it can be presumed that biotic homogenization occurs, which may reduce the species diversity and ecosystem services.

\section{Acknowledgements}

We thank the Laboratório de Ictiologia colleagues for their help during field work and Departamento de Zoologia e Botânica IBILCE-UNESP for facilities, IBAMA for collection license, landowners for permission to conduct research on their properties, David R. Mercer for language revision, Gabriel L. Brejão for calculations of the distances between sites. This study was made possible by funding from FAPESP in the BIOTA/FAPESP Program (www.biota.org/br). LC receives grant from CNPq; FBT, TGS, JOZ from FAPESP (2008/035839, 2008/58979-4, 2009/11169-0); ARM and CSG from Capes.

\section{Literature Cited}

Andrian, I. F., C. R. C. Dória, G. Torrente \& C. M. L. Ferretti. 1994. Espectro alimentar e similaridade na composição da dieta de quatro espécies de Leporinus (Characiformes, Anostomidae) do rio Paraná $\left(22^{\circ} 10^{\prime}-22^{\circ} 50^{\prime} \mathrm{S} 53^{\circ} 10^{\prime}-53^{\circ} 40^{\prime} \mathrm{W}\right)$, Brasil. Revista Unimar, 16: 97-106.

Angermeier, P. L. \& J. R. Karr. 1983. Fish communities along environmental gradients in a system of tropical streams. Environmental Biology of Fishes, 9: 117-135.

Araujo, R. B. \& V. Garutti. 2003. Ecology of a stream from upper Paraná river basin inhabited by Aspidoras fuscogutattus Nijssen and Isbrücker, 1976 (Siluriformes, Callichthyidae). Brazilian Journal of Biology, 63: 363-372.

Berkman, H. E. \& C. F. Rabeni. 1987. Effect of siltation on stream fish communities. Environmental Biology of Fishes, 18: 285-294.

Blanck, A., P. A. Tedesco \& N. Lamouroux. 2007. Relationships between life-history strategies of European freshwater fish species and their habitat preferences. Freshwater Biology, 52: 543-859.

Bojsen, B. H. \& R. Barriga. 2002. Effects of deforestation on fish community structure in Ecuadorian Amazon streams. Freshwater Biology, 47: 2246-2260.

Borcard, D., P. Legendre \& P. Drapeau. 1992. Partialling out the spatial component of ecological variation. Ecology, 73: 1045-1055.

Borcard, D., F. Gillet \& P. Legendre. 2011. Numerical Ecology with R. Springer, New York, 302p.

Bozzetti, M. \& U. H. Schulz. 2004. An index of biotic integrity based on fish assemblages for subtropical streams in southern Brazil. Hydrobiologia, 529: 133-144.

Brooks, A. P., P. Gehrke, J. D. Jansen \& T. B. Abbe. 2004. Experimental reintroduction of woody debris on the Williams River, NSW: Geomorphic and ecological responses. River Research \& Applications, 20: 513-536.

Bunn, S. E., P. M. Davies \& D. M. Kellaway. 1997. Contributions of sugar cane and invasive pasture grass to the aquatic food web of a tropical lowland stream. Marine and Freshwater Research, 48: 173-179.

Burcham, J. 1988. Fish communities and environmental characteristics of two lowland streams in Costa Rica. Revista de Biología Tropical, 36: 273-285.

Carvalho, E. M. \& V. S. Uieda. 2010. Input of litter in deforested and forested areas of a tropical headstream. Brazilian Journal of Biology, 70: 283-288.

Casatti, L. 2002. Alimentação dos peixes em um riacho do Parque Estadual Morro do Diabo, bacia do Alto Paraná, sudeste do Brasil. Biota Neotropica, 2: 1-14.

Castro, R. M. C. \& L. Casatti. 1997. The fish fauna from a small forest stream of the upper Paraná river basin, southeastern Brazil. Ichthyological Exploration of Freshwaters, 7: 337-352.

Casatti, L. \& R. M. C. Castro. 1998. A fish community of the São Francisco River headwater riffles, southeastern Brazil. Ichthyological Exploration of Freshwaters, 9: 229-242.

Casatti, L., F. Langeani \& R. M. C. Castro. 2001. Peixes de riacho do Parque Estadual Morro do Diabo, bacia do Alto rio Paraná, SP. Biota Neotropica, 1: 1-15.

Casatti, L., F. Langeani, A. M. Silva \& R. M. C. Castro. 2006. Stream fishes, water and habitat quality in a pasture dominated basin, southeastern Brazil. Brazilian Journal of Biology, 66: 681-696.

Casatti, L., C. P. Ferreira \& F. R. Carvalho. 2009. Grass-dominated stream sites exhibit low fish species diversity and dominance by guppies: an assessment of two tropical pasture river basins. Hydrobiologia, 632: 273-283.

Casatti, L., R. M. Romero, F. B. Teresa, J. Sabino \& F. Langeani. 2010. Fish community structure along a conservation gradient in Bodoquena Plateau streams, central West of Brazil. Acta Limnologica Brasiliensia, 22: 50-59. 
Chao, A. \& T.-J. Shen. 2010. Program SPADE (Species Prediction And Diversity Estimation). Program and User's Guide published at http://chao.stat.nthu.edu.tw

Chapman, L. J. \& C. A. Chapman. 2002. Tropical forest degradation and aquatic ecosystems: our current state of knowledge. Pp. 237249. In: Collares-Pereira, M. J., I. G. Cowx \& M. M. Coelho (Eds.). Conservation of freshwater fishes: options for the future. Oxford, Blackwell Science, 472p.

Clarke, K. R. \& R. N. Gorley. 2006. PRIMER v6: User manual/ Tutorial. Plymouth Marine Laboratory, Plymouth, UK.

Clarke, K. R. \& R. M. Warwick. 2001. Change in marine communities: an approach to statistical analysis and interpretation. Plymouth Marine Laboratory, Plymouth, UK.

Cortezzi, S. S., P. C. Bispo, G. P. Paciencia \& R. C. Leite. 2009. Influência da ação antrópica sobre a fauna de macroinvertebrados aquáticos em riachos de uma região de cerrado do sudoeste do Estado de São Paulo. Iheringia, Série Zoologia, 99: 36-43.

Colwell, R. K. 2005. EstimateS: statistical estimation of species richness and shared species from samples. Version 7.5.2. Available from http://www.purl.oclc.org/estimates (20/May/2011)

Crook, D. A. \& A. I. Robertson. 1999. Relationships between riverine fish and woody debris: implications for lowland rivers. Marine and Freshwater Research, 50: 942-953.

Daniels, M. D. \& B. L. Rhoads. 2004. Spatial pattern of turbulence kinetic energy and shear stress in a meander bend with large woody debris. Pp. 87-97. In: Bennett, S. J. \& A. Simon (Eds.). Riparian vegetation and fluvial geomorphology. Washington D.C., American Geophysical Union, 282p.

de Cáceres, M., P. Legendre \& M. Moretti. 2010. Improving indicator species analysis by combining groups of sites. Oikos, 119: 16741684.

Dray, S. D., P. L. \& P. R. Peres-Neto. 2006. Spatial modelling: a comprehensive framework for principal coordinate analysis of neighbour matrices (PCNM). Ecological Modelling, 196: 483-493.

ESRI, 2008. Environmental Systems Research Institute Inc. Redlands, CA.

Ferreira, A., N. S. Hahn \& R. L. Delariva. 2002. Ecologia alimentar de Piabina argentea Reinhardt (Teleostei, Tetragonopterinae) nas fases de pré e pós-represamento do rio Corumbá, GO. Acta Limnologica Brasiliensia, 14: 43-52.

Ferreira, C. P. 2010. Estrutura da ictiofauna e integridade biótica de riachos em fragmentos florestais remanescentes no noroeste paulista. Unpublished Ph.D. Dissertation, Universidade Estadual Paulista, São José do Rio Preto, 167p.

Ferreira, C. P. \& L. Casatti. 2006. Integridade biótica de um córrego na bacia do Alto Rio Paraná avaliada por meio da comunidade de peixes. Biota Neotropica, 6: 1-25.

Gibran, F. Z., K. M. Ferreira \& R. M. C. Castro. 2001. Diet of Crenicichla britskii (Perciformes: Cichlidae) in a stream of Rio Aguapeí basin, Upper Rio Paraná system, southeastern Brazil. Biota Neotropica, 1: 1-5.

Gregory, S. V., F. J. Swanson, W. A. McKee \& K. W. Cummins. 1991. An ecosystem perspective of riparian zones. Bioscience, 41: 540-551.

Growns, I., P. C. Gehrke, K. L. Astles \& D. A. Pollard. 2003. A comparison of fish assemblages associated with different riparian vegetation types in the Hawkesbury-Nepean River system. Fisheries Management and Ecology, 10: 209-220.

Harding, J. S., E. F. Benfield, P. V. Bolstad, G. S. Helfman \& E. B. D. Jones III. 1998. Stream biodiversity: the ghost of land use past. Proceedings of National Academy of Sciences, 95: 14843-14847.
Harvey, B. C. \& A. J. Stewart. 1991. Fish size and habitat depth relationships in headwater streams. Oecologia, 87: 336-342.

Instituto de Pesquisas Tecnológicas do Estado de São Paulo (IPT). 2000. Diagnóstico da situação atual dos recursos hídricos e estabelecimento de diretrizes técnicas para a elaboração do Plano da Bacia Hidrográfica do São José dos Dourados - minuta. Comitê da Bacia Hidrográfica do São José dos Dourados e Fundo Estadual de Recursos Hídricos.

Johnson, R. K. \& D. Hering. 2009. Response of taxonomic groups in streams to gradients in resource and habitat characteristics. Journal of Applied Ecology, 46: 175-186.

Kikuchi, R. M. \& V. S. Uieda. 1998. Composição da comunidade de invertebrados de um ambiente lótico tropical e sua variação espacial e temporal. Pp. 157-173. In: Nessimian, J. L. \& A. L. Carvalho (Eds.). Ecologia de insetos aquáticos. Série Oecologia Brasiliensis, vol. 5, PPGE-UFRJ, Rio de Janeiro.

Kramer, D. L. \& J. P. Mehegan. 1981. Aquatic surface respiration, an adaptative response to hypoxia in the guppy, Poecilia reticulata (Pisces, Poeciliidae). Environmental Biology of Fishes, 6: 299-313.

Landeiro, V. L., W. E. Magnusson, A. S. Melo, H. M. V. EspíritoSanto \& L. M. Bini. 2011. Spatial eigenfunction analyses in stream networks: do watercourse and overland distances produce different results? Freshwater Biology, 56: 1184-1192.

Lavorel, S., K. Grigulis, S. McIntyre, N. S. G. Williams, D. Garden, J. Dorrough, S. Berman, F. Quétier, A. Thébault \& A. Bonis. 2008. Assessing functional diversity in the field - methodology matters! Functional Ecology, 16: 134-147.

Lester, R. E., W. Wright \& M. Jones-Lennon. 2007. Does adding wood to agricultural streams enhance biodiversity? An experimental approach. Marine and Freshwater Research, 58: 687-698.

Lévêque, C., T. Oberdorff, D. Paugy, M. L. J. Stiassny \& P. A. Tedesco. 2008. Global diversity of fish (Pisces) in freshwater. Hydrobiologia, 595: 545-567.

Lorion, C. M. \& B. P. Kennedy. 2009. Riparian forest buffers mitigate the effects of deforestation on fish assemblages in tropical headwater streams. Ecological Applications, 19: 468-479.

Morgan II, R. P., J. Rasin Jr. \& L. A. Noe. 1983. Sediment effects on eggs and larvae of striped bass and white perch. Transactions of American Fisheries Society, 112: 220-224.

Naiman, R. J. \& H. Décamps. 1997. The ecology of interfaces: riparian zones. Annual Review of Ecology and Systematics, 28: 621-658.

Naiman, R. J., H. Décamps \& M. E. McClain. 2005. Riparia: ecology, conservation, and management of streamside communities. Burlington, Elsevier Academic Press, 448p.

Nalon, M. A., I. S. A. Matto \& G. A. D. C. Franco. 2008. Meio físico e aspectos da vegetação. Pp. 12-21. In: Rodrigues, R. R. \& V. L. R. Bononi (Orgs.). Diretrizes para conservação e restauração da biodiversidade no Estado de São Paulo. São Paulo, Instituto de Botânica, 248p.

Newmann, R. M. \& T. L. Wildman. 2002. Relationships between trout habitat use and woody debris in two southern New England streams. Ecology of Freshwater Fish, 11: 240-250.

Nimer, E. 1989. Climatologia do Brasil. Secretaria de Planejamento e Coordenação da Presidência da República, IBGE, Rio de Janeiro, $421 \mathrm{p}$.

Peres-Neto, P. R., P. Legendre, S. Dray, \& D. Borcard. 2006. Variation partitioning of species data matrices: estimation and comparison of fractions. Ecology, 87: 2614-2625.

Pinto, B. C. T., F. G. Araújo \& R. M. Hughes. 2006. Effects of landscape and riparian condition on a fish index of biotic integrity in a large southeastern Brazil river. Hydrobiologia, 556: 69-83. 
Power, M. 1984. Depth distributions of armored catfish: predatorinduced resource avoidance? Ecology, 65: 523-528.

Pusey, B. J. \& A. H. Arthington. 2003. Importance of the riparian zone to the conservation and management of freshwater fish: a review. Marine and Freshwater Research, 54: 1-16.

R Development Core Team. 2011. R: a language and environment for statistical computing. R Foundation for Statistical Computing, Vienna.

Rabeni, C. F. \& M. A. Smale. 1995. Effects on siltation on stream fishes and the potential mitigating role of the buffering riparian zone. Hydrobiologia, 303: 211-219.

Rocha, F. C., L. Casatti, F. R. Carvalho \& A. M. Silva. 2009. Fish assemblages in stream stretches occupied by cattail (Typhaceae, Angiospermae) stands in Southeast Brazil. Neotropical Ichthyology, 7: 241-250.

Schneider, K. N. \& K. O. Winemiller. 2008. Structural complexity of woody debris patches influences fish and macroinvertebrate species richness in a temperate floodplain-river system. Hydrobiologia, 610: 235-244.

Silva, A. M., L. Casatti, C. A. Álvares, A. M. Leite, L. A. Martinelli \& S. F. Durrant. 2007. Soil loss and habitat quality in streams of a meso-scale river basin. Scientia Agricola, 64: 336-343.

Stauffer, J. C., R. M. Goldstein \& R. M. Newman. 2000. Relationship of wooded riparian zones and runoff potential to fish community composition in agricultural streams. Canadian Journal of Fisheries and Aquatic Sciences, 57: 307-316.
Teels, B. M., A. A. Rewa \& J. Myers. 2006. Aquatic condition response to riparian buffer establishment. Wildlife Society Bulletin, 34: 927-935.

Tejerina-Garro, F. L., M. Maldonado, C. Ibañez, D. Pont, N. Roset \& T. Oberdorff, 2005. Effects of natural and anthropogenic environmental changes on riverine fish assemblages: a framework for ecological assessment of rivers. Brazilian Archives of Biology and Technology, 48: 91-108.

Teresa, F. B. \& L. Casatti. 2010. Importância da vegetação ripária em região intensamente desmatada no sudeste do Brasil: um estudo com peixes de riacho. Pan American Journal of Aquatic Sciences, 5: 444-453.

Teresa, F. B. \& R. M. Romero. 2010. Influence of the riparian zone phytophysiognomies on the longitudinal distribution of fishes: evidence from a Brazilian savanna stream. Neotropical Ichthyology, 8: 163-170.

Townsend, S. A. \& M. M. Douglas. 2000. The effect of three fire regimens on stream water quality, water yield and export coefficients in a tropical savanna (northern Australia). Journal of Hydrology, 229: 118-137.

Tundisi, J. G. \& T. M. Tundisi. 2008. Limnologia. São Paulo, Oficina de Textos, 631p.

Uieda, V. S., P. Buzzato \& R. M. Kikuchi. 1997. Partilha de recursos alimentares em peixes em um riacho de serra no sudeste do Brasil. Anais da Academia Brasileira de Ciências, 69: 243-252.

Submitted May 31, 2011

Accepted December 2, 2011

Published March 30, 2012 